\title{
Exploring the Impact of English Movies to Improve the Students' Listening Comprehension
}

\author{
Sam Hermansyah ${ }^{1}$, Hasan ${ }^{2}$ \\ Universitas Muhammadiyah Sidenreng Rappang, Indonesia ${ }^{1}$ \\ Universitas Muhammadiyah Enrekang, Indonesia ${ }^{2}$ \\ Email: ${ }^{1}$ samhermansyah@umsrappang.ac.id; ${ }^{2}$ achank.hasan80@gmail.com
}

\begin{tabular}{l} 
ARTICLE INFO \\
\hline Article History: \\
Received July 01, 2020 \\
Revised July 07, 2020 \\
Accepted July 13, 2020
\end{tabular}

Keywords:

English Movies,

Listening Comprehension, Attitudes

\begin{abstract}
The objective of this research was to improve the listening comprehension of the students of SMPN 1 Maiwa by using English Movies. The research aimed to see if English movies can improve the listening skills of students and to find out how students are using English Movies to increase their listening skills. The preexperimental method was used. Students from SMPN 1 Maiwa in 2018/2019, which comprises 20 students, were part of the research. Ten first-class students and 10 second-class students. In taking the sample, the author used a random sample. The researcher used data collection methods and questionnaires. The researcher has distributed listening tests by pre-testing and posttesting and sent questionnaires to gather information on their attitudes towards using English movies. Work suggests that the listening abilities of the students were poor in the preliminary examination. Their ability to listen is considerably increased after therapy. From their score, it can be seen that changed well. The findings evaluated with the t-test suggest that the t-test value is higher than the t-table (7.98>2.093). English Movies can be concluded to develop the listening skills of students.
\end{abstract}

Introduction

Listening is one of the keys to establishing effective communication. It has an important role in communication because most of our time we spend listening activity. Gilbert (2002) stated that listening is the most critical communication skill. Students are in a listening situation $65 \%$ to $90 \%$ of the 
time. Moreover, Harmer (1983) stated that nearly $50 \%$ of typical students' time spent in listening, the higher the grade level, the more time usually spent in listening. Many college students spent nearly $50 \%$ of their time listening to lectures and discussions. Listening skill is really important in our life. In order to make the communication can go smoothly, we must understand the speaker's message Underwood (1989) \& Fadli, M. Mangenre (2008) claimed listening is the practice to pay attention to what we hear and wish to make sense. Listening is not only an activity to hear the speaker's message but also to understand the meaning of the message conveyed (Deva, 2007).

Teachers have been trying many techniques to improve listening, from traditional to modern technology in teaching listening (Adnan, A. (2014). Using modern technology will be better than the traditional one (Ismail, I., Elihami, E., \& Mustakim, M., 2019). One of the modern technologies that can be applied and give a big contribution to improving listening ability is using movies as a media of teaching (Wordnet, 2008). Macavity (2005) stated that watching films can help to take the language away from the artificial classroom norm because they see/hear the language in a more natural setting. Louw (2008) also said that films convey language so that it is always easy to understand and listen, and that students absolutely love it, as is fantastic visual meaning.

In several literature studies related to listening shows the needs of the current students, especially students to improve listening comprehension. Gusrianti (1996) stated that teaching listening class by using native-speaker voice recorded materials is very helpful.
Malik (2001) also states that the third students' of MAN 1 Bulukumba have a favorable interest in learning listening comprehension by using songs in VCD. This finding is supported by the scores of pre-test and post-test. Sarkiah (2002) concluded that teaching listening comprehension by using VCD can improve the students' listening of the second-year student of LSTP Bulukumba. It was obviously seen that ttest was smaller than the t-value. While Nur Zam-Zam (2005) concludes that the Audio Lingual method is useful to help the students to improve their listening ability.

From the previous literature, the authors conclude that listening skills must be taught attractively to make students feel natural in learning them. However, from a variety of previous literature, researchers have not found learning to listen through English movies. In this study, researchers are interested in trying to use the English Movies technique to help students improve their listening and it is hoped that English Movie is one way to help students understand native speakers' speech. The main objectives of the research are: (1) Evaluate whether the use or not of English films will enhance listening skills for students. (2) explore the attitudes of the students towards enhancing their listening skills with English Movies. The research formulate the following research questions following the previous description: (1) to what extent can students increase their listening ability by using English movies? (2) to what degree is the attitude of students to English Movies application? The result of the research is expected to be useful information for English teacher about the usage of English Movie in teaching listening skill and is expected to 
be worthwhile information for all students (readers) so that they can utilize as a media, not only as entertainment but also to increase their knowledge. It is hoped that it gives a meaningful contribution to the students to improve their listening ability.

\section{Method}

The study used a pre-experimental framework in this research. The researcher collected information first before deciding the sample. The students at the school never using media in listening activity, the researcher decided to use only one class namely experimental class. The design that used was the one-group pretest-posttest design.

\section{Results}

The pre-test and post-test data analysis showed improvement following the course of treatment. The pre-test results showed that the students had poor listening skills. In the pre-test, only one student $(5 \%)$ had a very good mark from 20 students, $2(8 \%, 33 \%)$ had a relatively good mark, $11(5 \%)$ got a poor score and $6(30 \%)$ got a very poor mark. None of them have an excellent, good, and fair score. The student score was significantly improved during the posttest. This is demonstrated by three (15\%) students who have the excellent score, $3(15 \%)$ students who have the very good score, 9 (45\%) students who have the good score, $2(10 \%)$ students who have the moderate score, $1(5 \%)$ students who have the fair score, $2(5 \%)$ students who have the poor score. None of them had a very poor score. This indicates that the post-test ratio is higher than that of previous tests. This means that the listening capacity of the students has improved considerably.

The researcher found that they were substantially different based on a mean student score in the pre-test and posttesting. The average pre-test score for students has been 3.80 and 7.95. Then, the outcome of the T-test reveals that the $7.98 \mathrm{t}$-value is greater than the $2.093 \mathrm{t}$ table. This means that English films are an important teaching technique.

The average score of the students in the questionnaire, the researcher concluded that SMPN 1 Maiwa students have a positive attitude to the application of English movies. The consequence of the average score of 33.5 can be seen. This ensures that most students consent to the use of English movies.

\section{Conclusion}

Based on the results and the discussion, the researchers conclude that: (1) the listening abilities of students SMPN 1 Maiwa are rated as low before treatment, and then significantly improve their hearing ability after treatment. It can be seen from their aftertest, that their ability to listen has developed into a successful classification; (2) the application of English films is an important tool that can be used for teaching listening skills. This is reflected in the results of the t-test and t-test values where the values of $t-$ tests are above t-tests; (3) SMPN 1 Maiwa's students have a positive approach to the use of English Movies in their listening classes.

The researcher wishes to include some suggestions after this study: (1) English teacher should use a media that combined visual and auditory in 
teaching listening skills, so the students are not bored and enjoy the class. It will be better to use multimedia in teaching it. One of the good ways is by using English movies in their learning; (2) The researcher also suggested for the next researcher who are interested in this subject (listening) to find out the other way that more interesting than English Movies to teach listening because it is the most difficult skill in English.

\section{References:}

1) Adnan, A. (2014). Improving students' listening ability through movie report. Proceedings of ISELT FBS Universitas Negeri Padang, 2, 69-75.

2) Deva. 2007. How to Improve Your Listening. Retrieved from http:///www.englishbaby.com/f orum/AskEnglish/thread/91247

3) Fadli, M. Mangenre. 2008. Applying Top-Down Processing Strategy in Improving Listening Comprehension. A Thesis of UIN.

4) Farlex. 2009. Movie's Definition. Retrieved from http://www.thefreedictionary.co m/movie.

5) Hasan, H., \& Ismail, I. (2020). The Effectiveness of Material Based Stories in Improving Students Reading Comprehension. MAJESTY JOURNAL, 2(1), 40-46. https://doi.org/10.33487/majes ty.v2i1.332

6) Ismail, I., \& Tini. (2020). The Effect of formative assessment on students' grades in learning English. Maspul Journal of English Studies (Majesty Journal), 2(1), 20-30.

https://doi.org/10.33487/majes ty.v2i1.313
7) Jabri, U., \& Samad, I. (2019). The Use of Indonesian Slang by Makassar Families in Their Daily Interaction. MAJESTY JOURNAL, 1(2), 10-18. https://doi.org/10.33487/majesty.v $1 \mathrm{i} 2.116$

8) Musdalifah, M. (2019). The Comparison of Mind Mapping and Semantic Mapping to Enhance Reading Comprehension. MAJESTY JOURNAL, 1(2), 1-9. https://doi.org/10.33487/majes ty.v1i2.117

9) Ismail, I., Elihami, E., \& Mustakim, M. (2019). Students' Perceptions of the Benefits of Mobile Polling Technology in Teaching and Learning in College: Implications of Students' Participation and Academic Performance. Jurnal Pendidikan Progresif, 9(1), 89104. Retrieved from http://jurnal.fkip.unila.ac.id/ind ex.php/jpp/article/view/17871

10) Louw, Steve. 2008. Using Movies in the Classroom. Retrieved from http://www.teflasia.com/articles /Teacher-Talk/Using-Movies-inthe-classroom.html.

11) Macavity. 2006. How to Improve Listening Ability Substantially?. Retrieved from http://forum.wordreference.com /showthread.

12) Malik, Chaidir. 2001. The Achievement and the Interest of the Third Students of MAN 1 Bulukumba in Listening Comprehension by Using Song through VCD. A Thesis of FBS UNM.

13) Miller, Roziln. 2002. Listening Curriculum Resource Guide. Retrieved from 
Majesty Journal, 2 (2), 2020 - 36

Sam Hermansyah; Hasan

http://www.ostea.org/listening. htm.

14) Miyoko. 2009. Developing Teaching Material for Classroom Interaction in a Movie-Based Course. Retrieved from http://www.seigakuinuniv.ac.jp/pdf.

15) Nicholas, Wilga M. 1988. Teaching Listening Comprehension. The English Teaching Forum. Vol XXIV. No. 1 January.

16) Rasch. 2008. Definition of Ability. Retrieved from http://www.rasch.org/rmt/rmt1 52e.htm.

17) Sarkiah. 2002. Teaching Listening Comprehension by Using VCD to Second Year Students of SLTP Bulukumba. A Thesis FBS UNM.
18) Suriyana, S. 2008. Improving the Listening Ability through Listening Reading Transfer Lesson (LRTL). A Thesis of UIN.

19) Underwood, Mary. 1989. Teaching Listening. New York: Long Man Inc.

20) Wisma. 2007. Using Fables in Video Compact Disc (VCD) to Improve the Students Listening Comprehension. A Thesis of UIN.

21) Wordnet. 2008. Movie Definition. Retrieved from http://dictionary.die.net/movie.

22) Zam-Zam, Nur. 2005. The Application of Audio Lingual Method in Improving Listening Skill. A Thesis of UIN. 